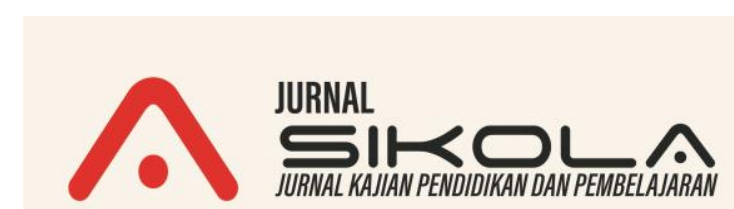

Jurnal Sikola: Jurnal Kajian Pendidikan dan Pembelajaran VOL. 1 NO. 2 DESEMBER 2019

http://sikola.ppj.unp.ac.id

Email: sikola@ppj.unp.ac.id

ISSN: 2686-3413 (Print) 2715-1735 (Online)

DOI: https://doi.org/10.24036/sikola.v1i2.14

\title{
Hubungan Interaksi Sosial Bentuk Akomodasi Guru-Siswa dengan Hasil Belajar Sosiologi Siswa SMA Negeri 3 Padang
}

\author{
Efriman Efriman ${ }^{1}$,Junaidi Junaidi ${ }^{2}$ \\ ${ }^{1,2}$ Universitas Negeri Padang \\ Email: efriman72@gmail.com, junaidiunp@fis.unp.ac.id.
}

\begin{abstract}
Abstrak
Penelitian ini dilatarbelakangi karena ketertarikan peneliti melihat hasil belajar siswa di SMA Negeri 3 Padang yang rendah akibat namun interaksi sosial yang terjadi antara guru dengan siswa berjalan dengan baik dan semestinya. Penelitian ini bertujuan untuk mengetahui hubungan antara interaksi sosial bentuk akomodasi dengan hasil belajar Sosiologi siswa SMA Negeri 3 Padang. Penelitian dianalisis dengan teori yang dikamukakan oleh Gegne dan Berliner. Di dalam penelitian ini digunakan suatu pendekatan kuantitaif Ex-Post Facto, teknik pemilihan proportional random sampling dan jumlah responden yang diambil 58 orang. Data sekunder dalam penelitian berupa hasil belajar dan dokumentasi yang dianalisis dengan menggunakan analisis data deskriptif data, pengumpulan data dilakukan dengan cara penyebarkan angket. Hasil dalam penelitian ini dapat dilihat bahwa terdapat yang signifikan dalam korelasi antara variabel interaksi sosial bentuk akomodasi dengan hasil belajar Sosiologi siswa SMA Negeri 3 Padang dibuktikan dengan koefisien korelasi $\left(\mathrm{r}_{\mathrm{xy}}\right) 0,459>\mathrm{r}_{\text {tabel }} 0,256$.
\end{abstract}

Kata kunci: Akomodasi, Hasil belajar, Interaksi Sosial.

\section{Abstract}

This research is motivated because the researchers are interested in seeing student learning outcomes in Padang 3 State High Schools which are low due to the sosial interaction that occurs between teachers and students going well and properly. This study aims to determine the relationship between sosial interaction accomodation with sociology learning outcomes of students of State Senior High School 3 Padang. The study was analyzed with the theory that was raged by Gegne and Berliner. This research uses an Ex-Post Facto quantitative approach, a proportional random sampling technique and the number of respondents taken by 58 people. Secondary data in research in the form of learning outcomes and documentation were analyzed using data analysis descriptive data, data collection is done by distributing questionnaires. The results in this study can be seen that there is a significant correlation between the variables of sosial interaction (accommodation) with sociology learning outcomes of students of State Senior High School 3 Padang proven by the correlation coefficient (rxy) 0, 459> rtable 0, 256.

Keywords: Accommodation, Learning Outcomes, Social interaction.

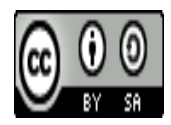

\begin{tabular}{|l|l|l|l|} 
Received: October 10, 2019 & Revised: December 11, 2019 & Accepted: December 13, 2019 \\
\hline
\end{tabular}

Jurnal Sikola: Jurnal Kajian Pendidikan dan Pembelajaran Vol. 1, No. 2, Th. 2019 


\section{Pendahuluan}

Pendidikan merupakan suatu kebutuhan yang penting dalam kehidupan manusia (Fernandes, 2017). Melalui pendidikan manusia dapat mengembangkan dirinya maupun mendayagunakan potensi alam dan lingkungan sosial untuk kepentingan hidupnya. Pendidikan juga suatu kebutuhan pokok dalam pembangunan bangsa dan negara

Sekolah menengah umum memiliki berbagai mata pelajaran yang bisa menjadi bekal untuk mengembangkan potensi, pengetahuan dan keterampilan dilingkungan hidupnya dimasyarakat. Adapun pelajaran yang berhubungan langsung dengan masyarakat adalah mata pelajaran Sosiologi. Pembelajaran ini salah satu pelajaran yang menunjang usaha dalam pencapaian tujuan pendidikan nasional, yang menjadi pusat pembelajaran ini yaitu hubungan antara individu dengan kelompok, individu dengan individu, dan kelompok dengan kelompok.

Pembelajaran ini bertujuan untuk mengarahkan siswa agar bisa memahami realita sosial, dinamika sosial dalam keanekaragaman budaya dalam kehidupan sehari-hari. Menurut (Depdiknas, 2003) karakteristik Sosiologi sebagai berikut: Sosiologi suatu displin intelektual mengenai pengembangan pengetahuan yang sistematis dan terandalkan tentang hubungan manusia pada umumnya, materi Sosiologi banyak mempelajari interaksi, perilaku keluarga, menelusuri asal-usul pertumbuhan, mengalisis juga melihat pengaruh dari kegiatan keluarga, tema-tema esensial dalam Sosiologi dipilih dan bersumber serta kajian tentang masyarakat dan perilaku manusia dalam meneliti kelompok yang dibangunnya. Kelompok itu mencakup keluarga, suku bangsa, komunitas, pemerintahan dan berbagai oraganisai-organisasi sosial, politik, bisnis dan agama, materi-materi sosial dikembangkan menjadi suatu lembaga pengetahuan ilmiah dan pengembangan teori yang berdasarkan pada observasi ilmiah, bukan lagi spekulatif di belakang meja dan observasi impresionis.

Berdasarkan karakteristik pembelajaran Sosiologi tersebut bahwa siswa tidak hanya dituntut untuk mengerti tentang teori mata pelajaran Sosiologi saja akan tetapi siswa juga bisa untuk mengaplikasikannya dalam kehidupan bermasyarakat. Besarnya peranan Sosiologi dalam kehidupan manusia diharapkan mata pelajaran Sosiologi di sekolah dapat difahami dan dikuasai oleh siswa. Mata pelajaran Sosiologi juga ikut serta dalam menetukan kelulusan siswa pada ujian nasional. Oleh sebab itu siswa dituntut untuk mencapai hasil belajar sesuai dengan tujuan pPendidikan merupakan suatu kebutuhan yang penting dalam kehidupan manusia (Fernandes, 2017). Melalui pendidikan manusia dapat mengembangkan dirinya maupun mendayagunakan potensi alam dan lingkungan sosial untuk kepentingan hidupnya. Pendidikan juga suatu kebutuhan pokok dalam pembangunan bangsa dan negaraembelajaran. (Muz Dalifa, 2019) Kenyataan di lapangan bahwa hasil belajar yang dicapai siswa di SMA Negeri 3 Padang masih rendah. Hal ini dapat dilihat dari rata-rata ujian UTS (ujian tengah semester) semester I tahun 2018-2019 Sosiologi siswa IPS SMA Negeri 3 Padang.

\section{Tabel 1. Nilai Rata-rata Ujian UTS (Ujian Tengah Semester) Semester I Tahun 2018-2019 Sosiologi IPS SMA Negeri 3 Padang}

\begin{tabular}{ccccc}
\hline No & Kelas & Nilai rata-rata & Jumlah siswa & KKM \\
\hline 1 & X IPS 1 & 72.75 & 36 & \\
\cline { 1 - 4 } 2 & X IPS 2 & 64.69 & 35 & \multirow{2}{*}{80} \\
\cline { 1 - 4 } 3 & XI IPS 1 & 78.88 & 36 & \\
\hline 4 & XI IPS 2 & 80.93 & 31 & \\
\hline
\end{tabular}

Sumber: Dokumen hasil UTS Semeseter I Juli-Des 2018 SMA Negeri 3 Padang

Dari tabel di atas nilai rata-rata UTS (ujian tengah semester) semester I IPS SMA Negeri 3 Padang pada mata pelajaran Sosiologi terlihat masih rendah(Anandari, 2013). Dari nilai ratarata tersebut dapat dilihat banyaknya siswa yang belum mencapai kriteria ketuntusan minimal

Jurnal Sikola: Jurnal Kajian Pendidikan dan Pembelajaran Vol. 1, No. 2, Th. 2019 
Efriman Efriman, Junaidi Junaidi Hubungan Interaksi Sosial (Akomodasi) Guru-Siswa dengan Hasil Belajar Sosiologi Siswa SMA Negeri 3 Padang (KKM) sebesar 80. Dari evaluasi kelas hanya satu kelas yang tuntas atau mencapai nilai KKM, satu kelas mendekati KKM dan ada dua kelas lagi yang masih jauh dari KKM.

Dalam (Slameto, 2010) adapun faktor-faktor yang mempengaruhi hasil belajar banyak jenisnya, tapi dapat digolongkan menjadi dua jenis saja, yaitu faktor intern dan faktor ekstern. Faktor internal adalah faktor yang ada dalam diri individu yang sedang belajar sedangkan faktor eksternadalah faktor yang ada di luar individu. Adapun faktor intern mencakup: faktor jasmaniah, faktor psikologis, faktor kelelahan, sedangkan faktor ekstern mencakup: faktor keluarga, faktor sekolah dan faktor masyarakat.

Dalam proses pembelajaran terjadi interaksi antara guru dengan siswa. Interaksi yaitu hubungan sosial yang dinamis, antara orang perorangan, kelompok dengan kelompok manusia maupun antara orang individu dengan kelompok manusia. (Soekanto, 2017) Adapun bentukbentuk dari interaksi tersebut berupa asosiatif dan disasosiatif. Dimana proses interaksi asosiatif seperti: kerja sama, akomodasi, asimilasi, sedangkan proses interaksi disasosiatif seperti: persaingan, kontravensi, pertikaian atau pertentangan. Berdasarkan studi pendahuluan melalui penyebaran angket diperoleh data bentuk interaksi siswa dengan guru yang terjadi di dalam kelas maupun di luar kelas SMA Negeri 3 Padang dalam bentuk:

Tabel 2. Bentuk Interaksi Sosial Antara Guru dan Siswa di Kelas IPS SMA Negeri 3 Padang

\begin{tabular}{|c|c|c|c|c|c|c|c|c|c|c|c|c|c|c|}
\hline \multirow{3}{*}{ No } & \multirow{3}{*}{$\begin{array}{l}\text { Bentuk } \\
\text { Interaksi }\end{array}$} & \multicolumn{8}{|c|}{ Kelas } & \multirow{3}{*}{ Jmlh } & \multirow{2}{*}{\multicolumn{4}{|c|}{ Jumlah \% }} \\
\hline & & \multicolumn{2}{|c|}{ XI IPS 1} & \multicolumn{2}{|c|}{ XI IPS 2} & \multicolumn{2}{|c|}{ XII IPS 1} & \multicolumn{2}{|c|}{ XII IPS 2} & & & & & \\
\hline & & $\mathrm{Y}$ & $\mathrm{T}$ & $\mathrm{Y}$ & $\mathrm{T}$ & $\mathrm{Y}$ & $\mathrm{T}$ & $\mathrm{Y}$ & $\mathrm{T}$ & & $\mathrm{Y}$ & $\%$ & $\mathrm{~T}$ & $\%$ \\
\hline \multicolumn{15}{|c|}{ Asosiatif } \\
\hline 1. & Kerja sama & 22 & 2 & 24 & - & 19 & 5 & 18 & 4 & 94 & 83 & $88 \%$ & 11 & $12 \%$ \\
\hline 2. & Akomodasi & 24 & - & 24 & - & 21 & 3 & 22 & - & 94 & 91 & $97 \%$ & 3 & $3 \%$ \\
\hline \multirow[t]{3}{*}{3.} & Asimilasi & 24 & - & 24 & - & 24 & - & 22 & - & 94 & 94 & $100 \%$ & 0 & 0 \\
\hline & Jumlah & 70 & 2 & 72 & 0 & 64 & 8 & 62 & 4 & 282 & & & & \\
\hline & \multicolumn{14}{|c|}{ Disasosiatif } \\
\hline 1. & Persaingan & 2 & 22 & - & 24 & 3 & 21 & 3 & 19 & 94 & 8 & $9 \%$ & 86 & $91 \%$ \\
\hline 2. & Kontravensi & - & 24 & - & 24 & 3 & 21 & - & 22 & 94 & 3 & $3 \%$ & 91 & $97 \%$ \\
\hline 3. & $\begin{array}{l}\text { Pertentangan } \\
\text { atau } \\
\text { pertikaian }\end{array}$ & - & 24 & - & 24 & 2 & 22 & - & 22 & 94 & 2 & $2 \%$ & 92 & $98 \%$ \\
\hline & Jumlah & 2 & 70 & 0 & 72 & 8 & 64 & 3 & 63 & 282 & & & & \\
\hline
\end{tabular}

Sumber: Diolah dari data angket 2019

Berdasarkan tabel di atas dapat disimpulkan bahwa interaksi sosial antara guru dengan siswa berjalan dengan baik, dimana dapat dilihat bentuk interaksi asosiatif asimilasi siswa sangat baik. Disamping itu, dari tiga bentuk interaksi asosiatif di atas, terlihat bahwa bentuk asimilasi memiliki skor yang paling tinggi, lalu diikuti dengan akomodasi. Asimilasi (Soekanto, 2012) adalah proses sosial yang ditandai dengan adanya usaha-usaha mengurangi perbedaan yeng terdapat antara individu atau kelompok-kelompok masyarakat meliputi usaha-usaha untuk mempertinggi kesatuan perilaku, sikap, dan proses mental yang memperhatikan tujuan dan kepentingan bersama. Secara singkat asimilasi adalah peleburan dua kebudayaan menjadi satu kebudayaan. Selanjutnya akomodasi adalah suatu keadaan yang memiliki kesimbangan (equibrium) interaksi antara individu dalam suatu masyarakat, atau berbagai usaha yang manusia untuk meredakan suatu pertentangan seperti usaha-usaha yang dilakukan untuk mencapai kestabilan. Akomodasi merupakan bentuk interaksi sosial (Tania Clara Dewanti, Widada, 2016) yang terjadi pada berbagai bidang. Salah satunya pada bidang pembelajaran. Dalam pembelajaran perlu akomodasi agar terjadi keseimbangan dalam bentuk interaksi antara

Jurnal Sikola: Jurnal Kajian Pendidikan dan Pembelajaran Vol. 1, No. 2, Th. 2019 
Efriman Efriman, Junaidi Junaidi

Hubungan Interaksi Sosial (Akomodasi) Guru-Siswa

dengan Hasil Belajar Sosiologi Siswa SMA Negeri 3 Padang

guru dengan siswa sehingga pertentangan-pertentangan yang terjadi ataupun mungkin terjadi dapat dihindari.

Akan tetapi walaupun interaksi sosialnya baik namun, hasil belajar yang diperoleh siswa masih banyak di bawah KKM. Oleh karena itu interaksi sosial bentuk akomodasi siswa dan guru di SMA Negeri 3 Padang menimbulkan pertanyaan bagi peneliti untuk mencari jawabannya. Dari uraian tabel di atas maka interaksi yang sesuai antara guru dengan siswa di dalam kelas selain kerjasama kadang ada juga terjadi pertentangan di antara siswa dengan guru karena adanya perbedaan pendapat atau juga keinginan.

Hasil belajar berasal dari dua kata yaitu "hasil" dan "belajar". Hasil (product) (Purwanto, 2009) merupakan suatu proses yang mengakibatkan berubahnya input secara fungsional atau suatu perolehan akibat dilakukannya suatu aktivitas. Sedangkan belajar (M. Syah, 2007) merupakan tahapan dari perubahan seluruh tingkah laku individu yang relatif tetap sebagai suatu hasill pengalaman dan interaksi yang melibatkan proses kognitif. Ruang lingkup hasil belajar antara lain: ranah kognitif, ranah efektif, dan ranah psikomotor. Faktor yang mempengaruhi hasil belajar antara lain: faktor intern dan faktor ekstern (Junaidi, n.d.-a).

Interaksi (Soekanto, 2017) adalah hubungan-hubungan sosial yang dinamis yang menyangkut hubungan antara orang perorangan, antara kelompok-kelompok manusia maupun antara orang perorangan dengan kelompok manusia. Faktor yang mempengaruhi interaksi antara lain: imitasi, sugesti, identifikasi, dan simpati. Bentuk dari interaksi ada interaksi sosial asosiatif, dan interaksi sosial disasosiatif. Proses sosial asosiatif dibagi kedalam: kerjasama, akomodasi, dan asimilasi sedangkan proses sosial disasosiatif terbagai kedalam: persaingan, kontrapensi, dan pertentangan atau pertikaian.

\section{Metode Penelitian}

Penelitian ini menggunakan metode kuantitatif jenis ex post facto. (Sukardi, 2008) Alasannya karena penulis mengkaji faktor-faktor yang diduga menjadi penyebab kejadian tersebut dan variabel-variabel bebas telah terjadi ketika peneliti mulai dengan pengamatan variabel terikat dalam suatu penelitian dan bersifat korelasi yakni bertujuan untuk mengetahui ada tidaknya hubungan antara dua variabel atau lebih.

\section{Hasil dan Pembahasan}

Studi ini dibuat untuk melihat seberapa besar hubungan interaksi sosial bentuk akomodasi guru-siswa dengan hasil belajar Sosiologi siswa, menggunakan metodologi korelasional dari dua variabel di atas. Pada proses pelaksanaannya digunakan paradigma fisiologi yang berkonsep morfologi. Paradigma ini dimaksudkan agar memudahkan dalam pemecahan masalah penelitian, dikarenakan paradigm ini yaitu suatu model berikir berdasarkan perubahan fisiologi dalam rangka mencapai kondisi yang lebih baik, dengan pola adaptasi fungsional dari berbagai indikator hubungan interaksi sosial bentuk akomodasi guru-siswa. Dalam penelitian ini, hubungan interaksis sosial bentuk akomodasi guru-siswa digunakan sebagai variabel bebas dan hasil belajar adalah variabel terikat. Hasil penelitian ini didapatkan dengan menggunakan penyebaran angket interaksi sosial bentuk akomodasi dan hasil belajar siswa. Berdasarkan hasil tes tersebut, maka interaksi sosial bentuk akomodasi dan hasil belajar masing-masing sampel dapat ditentukan. Sampel dalam penelitian ini berjumlah 58 orang siswa kelas X dan XI IPS SMA Negeri 3 Padang. Setelah selesai proses pengambilan sampel, lalu dilakukan penyebaran angket tentang interaksi sosial bentuk akomodasi dengan 4 indikator yaitu indikator kedua belah pihak bersedia memberi, kedua belah pihak bersedia menerima, kedua belah pihak berusaha mengubah sikap/ perilaku dan kedua belah pihak berusaha mengurangi kepentingan masingmasing serta hasil belajar terhadap variabel penelitian.

Uji normalitas digunakan agar mengetahui apakah distribusi data yang dilakukan mendekati atau mengikuti distribusi normal. Data yang baik merupakan data yang mempunyai pola distribusi normal yang memusatkan pada nilai rata-rata dan median,(Idris, 2010). Untuk

Jurnal Sikola: Jurnal Kajian Pendidikan dan Pembelajaran Vol. 1, No. 2, Th. 2019 
Efriman Efriman, Junaidi Junaidi Hubungan Interaksi Sosial (Akomodasi) Guru-Siswa dengan Hasil Belajar Sosiologi Siswa SMA Negeri 3 Padang mengetahui bentuk distribusi data dapat digunakan grafik distribusi dan analisis statistik. Normalitas ini dapat dilakukan dengan memakai metode Komlmogorov-Smirnov dengan kriteria pengujian sebagai berikut: Jika sig. Uji Kolmogorof-Smirnov $>0,5$ berarti variabel berdistributif normal dan Jika sig. Uji Kolmogorof-Smirnov < 0,5 berarti variabel tidak berdistributif normal. Hasil perhitungan uji normalitas dapat dilihat pada tabel diwah ini:

Tabel 3. Hasil Uji Normalitas

\begin{tabular}{|c|c|c|}
\hline \multicolumn{3}{|c|}{ One-Sample Kolmogorov-Smirnov Test } \\
\hline & & $\begin{array}{l}\text { Unstandardized } \\
\text { Residual }\end{array}$ \\
\hline $\mathrm{N}$ & & 58 \\
\hline \multirow{2}{*}{ Normal Parameters $a, b$} & Mean & 0000000 \\
\hline & Std. Deviation & 13,44408598 \\
\hline \multirow{3}{*}{ Most Extreme Differences } & Absolute & , 178 \\
\hline & Positive & ,098 \\
\hline & Negative &,- 178 \\
\hline Kolmogorov-Smirnov Z & & 1,352 \\
\hline Asymp. Sig. (2-tailed) & & 052 \\
\hline \multicolumn{3}{|c|}{ a. Test distribution is Normal. } \\
\hline \multicolumn{3}{|c|}{ b. Calculated from data. } \\
\hline
\end{tabular}

Dari tabel di atas diketahui bahwa nilai signifikan untuk semua variabel baik eksogen maupun endogen lebih besar dari alpha $=0,05$. Nilai signifikan $>0,05$ ini menunjukkan bahwa semua variabel tersebut datanya berdistribusi normal.

\section{Interaksi Guru dengan Siswa}

Dari variabel interaksi bentuk akomodasi (A.Nurwati, 2009) sosial guru dengan siswa dikumpulkan melalui angket yang terdiri dari 30 butir pernyataan dengan alternatif jawaban Selalu (SL), Sering (SR), Kadang-kadang (KD), Jarang (JR), dan Tidak Pernah (TP). Rentang skala 1-5 yang terdiri dari 4 indikator. Berikutnya angket diberikan kepada siswa kelas X dan XI IPS SMA Negeri 3 Padang sebanyak 58 orang untuk diisi oleh mereka. Dari data itu diketahui bahwa distribusi skor jawaban menyebar dari skor yang paling rendah 80 dan yang paling tinggi 100. Distribusi skor tersebut didapatkan dengan rata-rata skor (mean) sebesar 89, 776, skor tengah (median) 89, skor paling sering muncul (modus) 95, dan standar deviasi /simpangan baku 13, 844. Untuk melihat gambaran yang jelas tentang distribusi skor variabel hubungan interaksi sosial (akomodasi) guru dengan siswa pada tabel histogram berikut ini:

Tabe1 4. Distribusi Frekuensi Skor Hubungan Interaksi Sosial
Bentuk Akomodasi Guru-Siswa
\begin{tabular}{ccc}
\hline Kelas Interval & Frekuensi & Persentase \\
\hline $80-86$ & 18 & 31,03 \\
\hline $87-93$ & 22 & 37,93 \\
\hline $94-100$ & 18 & 31,03 \\
\hline Total & 58 & 100 \\
\hline Sumber: Pengolahan Data Primer (2019)
\end{tabular}

Dari tabel di atas gambaran hubungan interaksi sosial bentuk akomodasi menunjukkan bahwasanya terdapat 18 orang $(31,03 \%)$ responden memperoleh skor pada kelas interval 80-86, 22 orang $(37,93 \%)$ responden memperoleh skor pada kelas interval 87-93, dan 18 orang (31,

Jurnal Sikola: Jurnal Kajian Pendidikan dan Pembelajaran Vol. 1, No. 2, Th. 2019 

03\%) responden memperoleh skor pada interval 94-100. Lebih jelasnya lagi gambaran tentang hubungan interaksi sosial (akomodasi) guru- siswa dapat dilihat pada gambar di bawah ini:

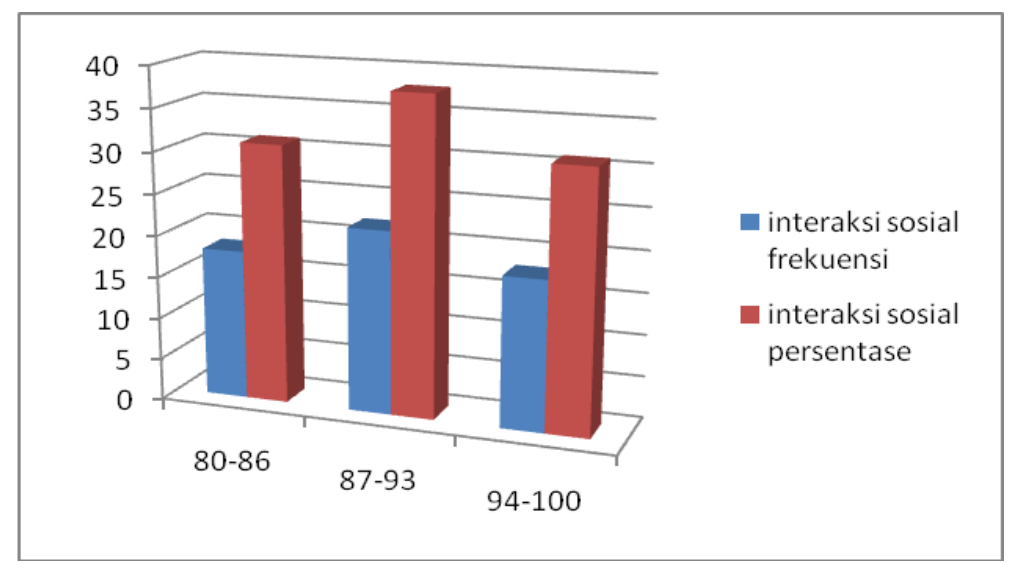

\section{Gambar 1. Histogram Skor Hubungan Interaksi Sosial Bentuk Akomodasi Guru-Siswa}

Dari data tersebut, diperoleh rata-rata tingkat capaian responden variabel hubungan interaksi sosial bentuk akomodasi guru dengan siswa sebesar 58, 85\%, dari skor ideal 150 , termasuk dalam kategori rendah. Dari data ini dapat dikatakan bahwa pada umumnya hubungan interaksi sosial bentuk akomodasi guru dengan siswa rendah.

\section{Hasil Belajar Sosiologi}

Variabel hasil belajar siswa diperoleh melalui data dokumentasi hasil tes kognitif UTS (ujian tengah semester) semester 1 tahun ajaran 2018/2019 kelas X IPS dan XI IPS SMA Negeri 3 Padang. Dari 58 orang yang dijadikan sebagai responden diperoleh distribusi nilai terendah sampai dengan tertinggi dan rata-rata (mean) sebesar 76, 534, nilai tengah (median) 81, nilai atau angka yang banyak muncul (modus) 84, dan standar deviasi atau simpangan baku 13, 844 .

Berdasarkan data tersebut dapat dilihat bahwa hasil belajar Sosiologi yang banyak diperoleh siswa adalah 84 . Nilai paling rendah 34 dan nilai paling tinggi dalah 96 sedangkan rata-rata hasil belajar siswa 76,844 . Siswa yang memperoleh nilai di atas rata-rata berarti hasil belajarnya tinggi sedangkan siswa yang nilainya di bawah rata-rata berarti hasil belajarnya rendah. Nilai mediannya 81 berarti 58\% dari frekuensi mendapat nilai diatas 81 dan $42 \%$ lagi mendapat nilai di bawah 81 . Modus 84 , artinya sebagian besar siswa mendapat nilai 84 pada mata pelajaran Sosiologi dari semua nilai yang ada. Untuk memperoleh gambaran yang jelas tentang distribusi nilai variabel hasil belajar dapat dilihat pada tabel histogram berikut ini:

Tabel 5. Distribusi Frekuensi Nilai Hasil Belajar

\begin{tabular}{ccc}
\hline Kelas Interval & Frekuensi & Persentase \\
\hline $34-42$ & 2 & 3,45 \\
\hline $43-51$ & 3 & 5,17 \\
\hline $52-60$ & 3 & 5,17 \\
\hline $61-69$ & 7 & 12,07 \\
\hline $70-78$ & 5 & 8,62 \\
\hline $79-87$ & 30 & 51,72 \\
\hline $88-96$ & 8 & 13,79 \\
\hline Rata-rata & 58 & 100 \\
\hline Sumber: Pengolahan Data Primer (2018/2019)
\end{tabular}

Jurnal Sikola: Jurnal Kajian Pendidikan dan Pembelajaran Vol. 1, No. 2, Th. 2019 
Dari tabel tersebut gambaran nilai hasil belajar siswa diperoleh 2 orang $(3,45 \%)$ responden nilainya berada pada kelas interval 34-42 (Nelpa Fitri Yuliani, 2013), 3 orang $(5,17 \%)$ responden nilainya berada pada kelas interval $43-51,3$ orang $(5,17 \%)$ responden nilainya berada pada kelas interval 52-60, 7 orang $(12,07 \%)$ responden nilainya berada pada kelas interval $61-69,5$ orang $(8,62 \%)$ responden nilainya berada pada kelas interval $70-78,30$ orang $(51,72 \%)$ responden nilainya berada pada kelas interval $79-87$, dan 8 orang $(13,79 \%)$ responden nilainya berada pada kelas interval 88-96. Lebih jelasnya gambaran tentang hasil belajar Sosiologi siswa dapat dilihat pada gambar di bawah ini:

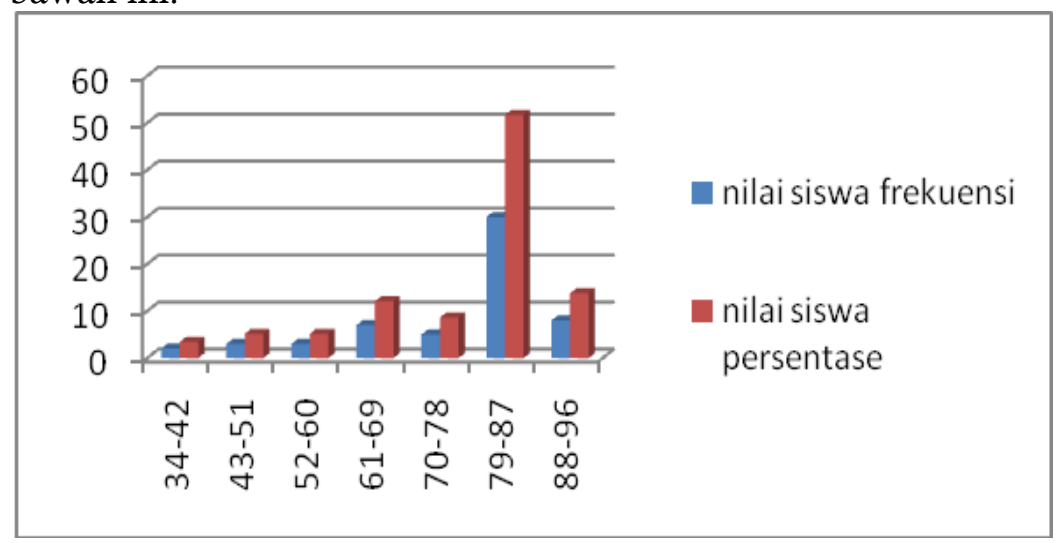

\section{Gambar 2. Rentangan Hasil Belajar Sosiologi Siswa}

Dari hasil di atas didapatkan dan diperoleh rata-rata tingkat capaian responden nilai hasil belajar sebesar 76, 53\%. Dari hasil di atas masuk kedalam kategori sedang/ cukup. Dari data ini dapat dikatakan bahwa secara keseluruhan hasil belajar siswa pada mata pelajaran Sosiologi di SMA Negeri 3 Padang sedang/ cukup. Keberhasilan yang ingin dicapai oleh siswa tentu tidak akan datang dengan sendirinya, karena itu siswa harus mampu mencapainya dengan memulai perencanaan yang matang serta pelaksanaan yang baik. Perencanaan guru dan siswa untuk memperoleh nilai yang baik harus diawali dengan target nilai yang baik pula begitu juga dengan pelaksanaannya (Sylvia, 2014), sehingga sangat diperlukan hubungan sosial yang baik khususnya inteaksi sosial antara guru dan siswa.

\section{Uji Hipotesis}

Berdasarkan uji hipotesisi yang dilakukan dengan menggunakan rumus korelasi ProductMoment, ternyata interaksi sosial bentuk akomodasi guru-siswa memiliki hubungan

Tabel 6. Hasil Analisis Korelasi

\begin{tabular}{c|c|c|c|c|c|c|c}
\hline Korelasi & $\mathbf{N}$ & $\mathbf{R}$ & $\mathbf{r}^{2}$ & $\mathbf{r}$ hitung & $\mathbf{r}$ table & Sig & Ket \\
\hline Rxy & 58 & 0,239 & 0,057 & 0,459 & 0,256 & 0,05 & Signifikan \\
\hline
\end{tabular}

Sumber: Pengolahan data primer 2019

Berdasarkan dari hasil uji hipotesis di atas menunjukkan bahwa terdapat hubungan antara interaksi sosial bentuk akomodasi guru-siswa dengan hasil belajar Sosiologi. Di samping itu penelitian ini, peneliti menganalisis indikator-indikator dari interaksi sosial bentuk akomodasi guru-siswa. Hal ini dapat dilihat pada tabel berikut:

Tabel 7. Hasil Uji Hubungan Antara Indikator Interaksi Sosial Bentuk Akomodasi GuruSiswa dengan Hasil Belajar Sosiologi

\begin{tabular}{ccccc}
\hline $\begin{array}{c}\text { Perbandingan } \\
\text { harga } \mathrm{r}\end{array}$ & Indikator 1 & Indikator 2 & Indikator 3 & Indikator 4 \\
\hline
\end{tabular}

Jurnal Sikola: Jurnal Kajian Pendidikan dan Pembelajaran Vol. 1, No. 2, Th. 2019 
Efriman Efriman, Junaidi Junaidi

Hubungan Interaksi Sosial (Akomodasi) Guru-Siswa dengan Hasil Belajar Sosiologi Siswa SMA Negeri 3 Padang

\begin{tabular}{ccccc}
\hline $\mathrm{r}_{\text {hitung }}$ & 0,324 & 0,399 & 0,437 & 0,598 \\
\hline $\mathrm{r}_{\text {tabel }}$ & 0,256 & 0,256 & 0,256 & 0,256 \\
\hline
\end{tabular}

Dari uji hipotesis terhadap indikator-indikator interaksi sosial bentuk akomodasi gurusiswa dapat dilihat bahwa indikator 1, kedua belah pihak bersedia memberi diperoleh uji hipotesis $\mathrm{r}_{\text {hitung }} 0,324>\mathrm{r}_{\text {tabel }} 0,256$. Hal ini berarti bahwa kedua belah pihak bersedia memberi di dalam proses pembelajaran memiliki hubungan dengan hasil belajar Sosiologi. Indikator ke 2, kedua belah pihak bersedia menerima diperoleh uji hipotesi $r_{\text {hitung }} 0,399>r_{\text {tabel }} 0,256$. Hal ini berarti bahwa kedua belah pihak bersedia menerima di dalam proses pembelajaran memiliki hubungan dengan hasil belajar Sosiologi. Indikator ke 3, kedua belah pihak berusaha mengubah sikap/ perilaku diperoleh uji hipotesi $\mathrm{r}_{\text {hitung }} 0,437>\mathrm{r}_{\text {tabel }} 0,256$. Hal ini berarti bahwa kedua belah pihak berusaha mengubah sikap/ perilaku di dalam proses pembelajaran memiliki hubungan dengan hasil belajar Sosiologi. Indikator ke 4, kedua belah pihak berusaha mengurangi kepentingan masing-masing diperoleh uji hipotesi $r_{\text {hitung }} 0,598>r_{\text {tabel }} 0,256$. Hal ini berarti bahwa kedua belah pihak berusaha mengurangi kepentingan masing-masing di dalam proses pembelajaran memiliki hubungan dengan hasil belajar Sosiologi. Dengan demikian, hipotesis Ho yang diajukan dalam penelitian ini ditolak, dan sebaliknya $\mathrm{H}$ diterima. Dengan kata lain belum terdapat hubungan antara interaksi sosial bentuk akomodasi guru dengan siswa dengan hasil belajar Sosiologi di SMA Negeri 3 Padang.

\section{Kedua belah pihak bersedia memberi}

Interaksi sosial bentuk akomodasi guru dengan siswa dilihat dari segi kedua belah pihak bersedia memberi memperoleh nilai $\mathrm{r}_{\text {hitung }} 0,324$ yang lebih tinggi dari $\mathrm{r}_{\text {tabel }} 0,256$ berarti kemampuan kedua belah pihak bersedia memberi merupakan salah satu tugas guru dalam membina hubungan antar pribadi. Dengan dikembangkan sikap kedua belah pihak bersedia memberi dalam proses pembelajaran, maka siswa akan lebih termotivasi untuk belajar sehingga hasil belajar siswa juga sesuai dengan yang diharapkan.

\section{Kedua belah pihak bersedia menerima}

Interaksi sosial bentuk akomodasi guru dengan siswa dilihat dari segi kedua belah pihak bersedia menerima memiliki hubungan dengan hasil belajar Sosiologi siswa terlihat dari $\mathrm{r}_{\text {hitung }} 0$, 399 yang lebih tinggi dari $\mathrm{r}_{\text {tabel }} 0,256$. Kedua belah pihak bersedia menerima sangatlah penting dalam proses pembelajaran seperti menerima pendapat siswa, menunjukkan sikap terbuka dan lapang dada jika siswa memberikan pandangan yang berbeda dalam proses pembelajaran Sosiologi. Dengan

berkembangnya sikap kedua belah pihak bersedia menerima dalam proses pembelajaran, maka siswa akan termotivasi untuk belajar dan hasil yang didapatkan juga memuaskan.

\section{Kedua belah pihak berusaha mengubah sikap/ perilaku}

Interaksi sosial bentuk akomodasi guru dengan siswa dilihat dari segi kedua belah pihak berusaha mengubah sikap/ perilaku dalam proses pembelajaran Sosiologi memperoleh nilai $\mathrm{r}_{\text {hitung }}$ 0,437 yang lebih tinggi dari $\mathrm{r}_{\text {tabel }} 0,256$. Kedua belah pihak berusaha mengubah sikap/perilaku dalam proses pembelajran Sosiologi, maka siswa akan lebih giat lagi untuk belajar dan hasil yang diharapkan juga akan baik.

\section{Kedua belah pihak berusaha mengurangi kepentingan masing-masing}

Interaksi sosial bentuk akomodasi guru dengan siswa dilihat dari segi kedua belah pihak berusaha mengurangi kepentingan masing-masing dalam proses pembelajaran Sosiologi memperoleh nilai $r_{\text {hitung }} 0,598$ yang lebih tinggi dari $\mathrm{r}_{\text {tabel }} 0$, 256. Kedua belah pihak berusaha mengurangi kepentingan masing-masing dalam proses pembelajran Sosiologi, maka siswa akan lebih giat lagi untuk belajar dan hasil yang diharapkan juga akan memuaskan.

Jurnal Sikola: Jurnal Kajian Pendidikan dan Pembelajaran Vol. 1, No. 2, Th. 2019 
Efriman Efriman, Junaidi Junaidi Hubungan Interaksi Sosial (Akomodasi) Guru-Siswa dengan Hasil Belajar Sosiologi Siswa SMA Negeri 3 Padang

Interaksi sosial bentuk akomodasi antara guru dengan siswa merupakan salah satu faktor yang dapat menjadi pendorong bagi siswa dalam proses pembelajaran untuk memperoleh hasil belajar Sosiologi yang optimal. Kegiatan pembelajaran di kelas adalah suatu kegiatan yang interaktif yaitu karena ada interaksi berkelanjutan atau kontiniu antara guru dengan siswa. Interaksi yang terjadi kelas secara baik antara guru dengan siswa sangatlah penting untuk meningkatkan aktifitas belajar.

Interaksi sosial dalam proses belajar mengajar, seorang guru memiliki peranan sangat yang penting, karena, alat apapun yang digunakan dan bagaimana keadaan anak didik, bagaimanapun keadaan sistem pendidikan, pada akhirnya gurulah yang menentukan dan memanfaatkan semua komponen yang ada (Junaidi, n.d.-b). Hubungan yang saling membutuhkan antara guru dengan siswa perlu senantiasa dijaga karena hal ini memiliki arti yang penting bagi siswa. Dimana siswa akan menciptakan suasana yang akrab sehingga dapat mendorong anak ntuk belajar (Soetomo, 1993). Contohnya dalam proses belajar mengajar, ketika seorang siswa tidak faham dengan materi yang disampaikan tersebut, maka akan terjadi interaksi komunikasi antara guru dengan siswa. Adanya interaksi itu, maka setiap materi yang tidak dimengerti siswa, siswa tidak akan segan dapat menyatakan langsung kepada guru sehingga terdapatnya motivasi pada diri siswa tersebut. Dengan motivasi itu diharapkan hasil belajar yang diperoleh oleh siswa akan meningkat.

Kenyataan di atas sesuai dengan Teori Koneksionisme yang sangat mementingkan pada stimulus dan respon. Jika sebuah stimulus ada maka responpun akan ada begitu seterusnya. Teori ini adalah suatu teori psikologis lebih melihat kepada perubahan yang diakibatkan pada pengaruh lingkungan ekstern dan intern.

Jika teori tersebut dapat diterapkan dalam suasana proses pembelajran, sesuai dengan penelitian yang dilakukan dapat disimpulkan bahwanya siswa yang sudah memiliki interaksi baik, dapat melakukan respon yang baik dalam pembelajaran Sosiologi secara baik dan optimal, kerena siswa akan melakukan suatu kegiatan yang mendukung proses pembelajaran sehingga dapat mempengaruhi hasil belajar Sosiologi diperoleh.

\section{Kesimpulan}

Berdasarkan hasil penelitian yang dilakukan di SMA Negeri 3 Padang dapat disimpulkan terdapat korelasi yang signifikan antara variabel interaksi sosial bentuk akomodasi guru-siswa dengan hasil belajar Sosiologi siswa SMA Negeri 3 Padang yang dibuktikan dengan koefisien korelasi $\left(\mathrm{r}_{\mathrm{xy}}\right)$ 0, 459> $\mathrm{r}$ tabel 0 , 256. Berarti H0 ditolak dan H1 diterima, sehingga hipotesis "terdapat hubungan signifikan interaksi sosial bentuk akomodasi guru-siswa dengan hasil belajar Sosiologi siswa SMA Negeri 3 Padang" diterima. Uji hipotesis per indikator interaksi sosial bentuk akomodasi guru-siswa dengan hasil belajar Sosiologi siswa menunjukkan hubungan signifikan dan memberikan kontribusi yang bermakna. Yang dibuktikan dengan nilai $\mathrm{r}_{\text {hitung }}>\mathrm{r}$ tabel. Dimana nilai $r_{\text {hitung masing-masing indikator secara berurutan adalah } 0.324,0.399,0.437}$ dan 0. 598> $\mathrm{r}_{\text {abel }}$ 0. 256. Berdasarkan hasil penelitian dapat diketahui bahwa ke 4 indikator tersebut memiliki pengaruh yang signifikan terhadap hasil belajar Sosiologi siswa, maka guru harus bisa mengembangkan dan menjalankan sikap tersebut dalam proses pembelajaran, agar siswa termotivasi untuk belajar dan hasil belajar yang diharapkan juga sesuai dengan yang diharapkan/ inginkan.

\section{Daftar Pustaka}

A.Nurwati. (2009). Hubungan Antara Interaksi Sosial Siswa Dengan Prestasi Belajar Bahasa Indonesia Siswa Madrasah Ibtidaiyah Se-Kabupaten Gorontalo. Cakrawala Pendidikan.

Anandari, D. S. (2013). Hubungan Persepsi Siswa atas Dukungan Sosial Guru dengan Self-Efficacy Pelajaran Matematika pada Siswa SMA Negeri 14 Surabaya (Relationship between Student

Jurnal Sikola: Jurnal Kajian Pendidikan dan Pembelajaran Vol. 1, No. 2, Th. 2019 
Efriman Efriman, Junaidi Junaidi Hubungan Interaksi Sosial (Akomodasi) Guru-Siswa

dengan Hasil Belajar Sosiologi Siswa SMA Negeri 3 Padang

Perception of Teacher Social Support with Mathematics Self-Efficacy on Student of SMA Negeri 14 Surabaya). 2(03).

Depdiknas. (2003). Standar Kompetensi Pelajar Sosiologi SMA dan MA. Jakarta: Pusat Kurikulum Badan Penelitian dan Pengembangan.

Fernandes, R. (2017). Adaptasi Sekolah Terhadap Kebijakan Pendidikan Inklusif. Jurnal Socius, 4.

Idris. (2010). Aplikasi Model AnalisisnData Kuantitatif dengan Program SPSS. Padang: FE UNP.

Junaidi. (n.d.-a). Strategi Menguasai Materi Ajar Dalam Perkuliahan Micro Teaching pada Mahasiswa Jurusan Sosiologi FIS UNP.

Junaidi. (n.d.-b). Sumber Belajar Dalam Membelajarkan Sosiologi.

M. Syah. (2007). Psikologi Belajar. Jakarta: PT. Raja Grafindo.

Muz Dalifa. (2019). Hubungan Antara Perhatian Orang Tua dengan Hasil Belajar Sosiologi Kelas XI IPS di SMAN 2 Padang. Kajian Pendidikan Dan Pembelajaran, 1 No. 1.

Nelpa Fitri Yuliani. (2013). Hubungan Antara Lingkungan Sosial dengan Motivasi Belajar Santri di Pesantren Madinatul Ilmi Islamiyah. Spektrum pls, 1 NO. 2.

Purwanto. (2009). Evaluasi Hasil Belajar. Yogyakarta: Pustaka Pelajar.

Slameto. (2010). Belajar dan Fakto-faktor yang Mempengaruhinya. Jakarta: Rineka Cipta.

Soekanto, S. (2012). Sosiologi Suatu Pengantar. Jakarta: Rajawali Pers.

Soekanto, S. (2017). Sosiologi Suatu Pengantar. Jakarta: PT RajaGrafindo Persada.

Soetomo. (1993). Dasar-Dasar Interaksi Belajar Mengajar. Surabaya: Usaha Nasioanal.

Sukardi. (2008). Metodeologi Penelitian Pendidikan. Jakarta: Bumi Aksara.

Sylvia, I. (2014). Hubungan Daya Juang Siswa dengan Hasil Belajar Sosiologi Siswa Kelas XI IPS SMAN I Tanjung Raya Kab. Agam. Diakronika, Vol. XIV No.1 Th. 2014, XIV(1), 97114. https://doi.org/https://osf.io/preprints/inarxiv/6yz2w/

Tania Clara Dewanti, Widada, T. (2016). Hubungan Keterampilan Sosial Dan Penggunaan Gadget Smartphone Dengan Prestasi Belajar Siswa Sma Negeri 9 Malang. Kajian Bimbingan Dan Konseling, 1 No 3. 